\title{
Cash-Flow Taxes in an International Setting
}

\author{
Alan J. Auerbach \\ University of California, Berkeley \\ Michael P. Devereux \\ Oxford University Centre for Business Taxation, \\ Saïd Business School, Oxford
}

This version: November 12, 2017

\begin{abstract}
This paper models the effects of cash-flow taxes on company profit which differ according to the location of the tax. The model incorporates a multinational producing and selling in two countries with three sources of economic rent, each in a different location: a fixed basic production factor (located with initial production), mobile managerial skill, and a fixed final production factor (located with consumption). In the general case, national governments face trade-offs in choosing between alternative taxes. In particular, a cash-flow tax on a source basis creates welfare-impairing distortions to production and consumption, but is partially incident on the owners of domestic production who may be non-resident. By contrast, a destination-based cash-flow tax does not distort behavior, but is incident only on domestic residents.
\end{abstract}

Keywords: Profit-shifting, destination-based taxation, transfer pricing

\section{Acknowledgements}

We would like to thank the editor, Matthew Shapiro, two anonymous referees, Steve Bond, Mick Keen, seminar participants at the Centre for Business Taxation, the Oxford University Economics department, the IFS-STICERD public economics seminar, Goethe University, Norwegian Business School and Stanford University for helpful comments and Chris Jauregui for outstanding programming to carry out the paper's simulations. Devereux acknowledges the financial support of the ESRC under grant RES-060-25-0033. 


\section{Introduction}

It is generally understood that the distortionary effects of capital income taxation are magnified in open economies. For example, standard theory (e.g., Gordon, 1986) suggests that the optimal rate of a source-based capital income tax is zero in a small open economy. Imposing a positive tax rate raises the required rate of return, reducing the domestic capital stock and causing deadweight loss. The incidence of the tax is on immobile domestic residents - who could be taxed directly without creating the deadweight loss.

In light of these effects, two potential dimensions of reform are available. The first is to tax only profit or economic rent. The properties of such a tax are well known. For example, Meade et al (1978) evaluated a cash-flow tax, which by taxing all revenues and giving a deduction for all costs, when incurred, would fall only on economic rent. Given that the properties of a tax on economic rent are well known, at least in a domestic setting, this paper focuses primarily on the second dimension: the location in which the economic rent is taxed. Evidence suggests that, in an international setting, even a source-based tax on economic rent can distort the discrete choice as to where to locate a profitable investment. This evidence relies on the sensitivity of such discrete location choices and also crossborder investment flows to average, rather than marginal, tax rates (see Devereux and Griffith, 1998, and the meta-analysis of de Mooij and Ederveen, 2008).

This paper explores in detail the two primary alternative locations for cash-flow taxes, demonstrating that there are two key elements of the optimal choice between alternatives: the deadweight loss associated with distortions to production and consumption, and the extent to which the incidence of the tax is exported to non-residents. 
We begin with a cash-flow tax in a conventional source-based setting. ${ }^{1}$ The main alternative that we consider is a destination-based tax which, like the common VAT, has border adjustments that zero-rate exports but tax imports, in addition to the immediate expensing of capital also present under the source-based cash-flow tax. As we demonstrate, in our setting such a tax has the merit of not creating a deadweight loss, and is therefore worthy of analysis. ${ }^{2}$ It has also recently been proposed in the United States (US House of Representatives, 2016) and is thus clearly of policy interest. ${ }^{3} \mathrm{~A}$ thorough analysis of these two systems provides a helpful starting point for a discussion of two more: the sourcebased capital income tax, which taxes the normal return to capital in addition to profits, and which is arguably closest to existing tax systems; and a cash-flow tax where the tax base is allocated by an apportionment factor based on the location of sales. Sales apportionment is increasingly used for the allocation of taxable profit among US states and also forms part of the European Commission's proposals for a formula apportionment system in the EU (European Commission, 2016); it is therefore also of policy interest.

We identify precisely the different channels by which even taxes on pure profits can affect economic behavior. For example, consider the effects of source-based cash-flow taxes applied to a company in both countries, where the home country has a higher tax rate.

\footnotetext{
${ }^{1}$ Most countries tax only domestic-source income. An exception is the United States, which taxes profits repatriated from the rest of the world, with a credit for foreign taxes already paid. In doing so, it raises little revenue but creates significant distortions. We do not model such a tax base in this paper.

${ }^{2}$ Bond and Devereux (2002) first analyzed a destination-based cash-flow tax in the context of discrete location choices.

${ }^{3}$ The US proposal would also have made interest non-deductible, thus creating a cash-flow tax akin to the Meade (1978) R-base. This can be distinguished from the R+F base which includes flows of debt, which is equivalent to the S-base on net dividend payments. As we do not include debt in our model, these are equivalent for the purposes of this paper. Note that with a deduction for the costs of depreciation and debt, existing taxes are arguably closer to a cash-flow tax than a capital income tax for debt-financed investments. We abstract from other elements of the US proposal, including those on personal taxes.
} 
Other things being equal, the company would prefer to shift production to the foreign, lower-taxed country, and export the good back to the home country to serve the domestic market. In addition, the company would have an incentive to inflate the reported internal transfer price at which the good is "sold" back to its domestic operation, since this would raise taxable profit in the foreign country and reduce it in the home country. This in turn creates a further incentive to shift production to the foreign country. So, even under a cashflow tax, the company would have an incentive to shift production to the foreign country, where the tax rate is lower. By contrast, a destination-based cash-flow tax implemented in both countries along the lines of a VAT (but with labor costs deductible) would be efficient. This stems from the assumption that the representative consumer is immobile. A tax based on sales revenue location cannot be avoided by moving production between countries.

International tax reform is likely to occur only when it is in the national interest of individual governments, so it is useful to consider whether a unilateral deviation from a common tax system would benefit the adopting country. A natural starting point for this analysis is source-based taxation, which is closest to the existing system. Beginning with a source-based cash-flow tax, we investigate whether a country would have an incentive to switch at least part of its tax system to one of the other two forms of cash-flow taxation.

In a non-cooperative setting, relative to a destination-based tax, there is generally a trade-off for governments in relying on source-based cash-flow taxation. On the one hand, a higher tax rate on a source base induces a deadweight cost due to distortions induced by a switch of production between countries; on the other hand the country benefits since part of the incidence of the tax falls on non-residents. Neither of these effects occurs under a destination-based cash-flow tax. 
These differences between source-based and destination-based taxes may appear to be at odds with several claims in the literature regarding the equivalence of destinationand source-based taxes, but the apparent inconsistency simply reflects differences in assumptions. We show in this paper the nature of the assumptions that need to be made for such an equivalence to hold. In particular, where the rent accruing to fixed factors is captured by local residents and there is no manipulation of transfer prices, production distortions would disappear and the source-based cash-flow tax, like the destination-based tax, would be equivalent to a lump-sum tax. This is implicitly the framework underlying the contributions of Auerbach (1997), Bradford (2003), Avi-Yonah (2000), Grubert and Newlon (1997) and others, resulting in the claim of equivalence. Huizinga and Nielsen (1997) make similar implicit assumptions in modeling a source-based tax on economic rent which is non-distorting, but which can be partly exported to non-residents; their main focus is on the nature of optimal capital income taxes when not all revenue needs can be met by the source-based tax on rent.

Our analysis also relates closely to the literature comparing a VAT levied on a destination or origin (i.e. source) basis since the destination-based cash-flow tax could be levied as a VAT together with a payroll subsidy. ${ }^{4} \mathrm{~A}$ comprehensive analysis of alternative locations of the VAT base was provided by Lockwood (2001), who synthesized a number of earlier contributions, including Lockwood (1993) and Keen and Lahiri (1998). Our model differs substantially, focusing particularly on firm-level decisions and several variations in

\footnotetext{
${ }^{4}$ We do not dwell here on the choice between direct implementation of a destination-based cash-flow tax and implementation via VAT cum payroll subsidy, a choice that could be influenced by a number of factors, including whether a country already has in place a VAT and a payroll tax that can be adjusted, whether these existing taxes are sufficiently broad-based to be suitable vehicles for the tax reform, and political and legal distinctions unrelated to economic considerations.
} 
tax structure as opposed to modeling the consumption side in more detail. Nevertheless, the results are broadly consistent: in particular, Lockwood finds that destination and origin bases are only equivalent with factor immobility. In the absence of transfer pricing manipulation, this would also be true in our model. ${ }^{5}$ Note that we do not focus on administrative and implementation issues in this paper; such questions have been addressed in the non-technical analysis of Auerbach et al (2017).

The remainder of the paper is organized as follows. Section 2 sets up the base case model. Section 3 analyzes the impact of the source-based and destination-based cash-flow taxes when both countries adopt the same form of taxation; it also briefly considers the source-based capital income tax. Section 4 addresses the question of whether, starting from source-based cash flow taxation in both countries, the home country has an incentive to switch part of its tax base to a destination-based cash-flow tax. Section 5 brings into the analysis the source-based capital income tax and the sales-apportioned cash-flow tax. As we show, starting with the source-based capital income tax, both elements of the trade-off in moving to a destination-based cash-flow tax are heightened; there are additional distortions to the taxation of marginal investment projects, and the marginal impact of tax exporting may be greater due to the broader tax base. As to sales apportionment, though it has been likened by some to destination-based taxation, it retains both features of the source-based tax - the deadweight costs arising from distortions, and the exporting of the tax to non-residents. The case for switching therefore depends on the relative sizes of these two factors.

\footnotetext{
${ }^{5}$ Beyond this, Lockwood also finds that imperfect competition destroys this equivalence.
} 
Section 6 concludes and offers a summary of results. The Appendix collects several derivations and extensions and presents a numerical Cobb-Douglas simulation model, which is used to illustrate the results in Sections 3 and 4.

\section{The Model}

For our analysis, we construct a model that incorporates, in as simple a manner as possible, the elements that contribute to differences among tax systems, including firmspecific factors of production, intangible assets, the international location of activities and cross-country ownership. In this model, a representative, price-taking multinational company is owned by representative consumers in each country. The company produces an intermediate good in both countries, which is then used for final goods production in both countries. The intermediate good is transformed into the final good in the country in which it is sold and consumed. This second process may reflect differences in the final good between countries depending on local conditions; for example, it may reflect advertising, distribution, and other activities that take place in the proximity of consumption.

The company generates profit in three ways, and in three locations. First, it has the use of a fixed factor in each production location of the intermediate good, which implies that there are decreasing returns to scale in the other two factors, capital and managerial skill. The existence of the fixed factor generates profit in the country of intermediate good production. This factor can be thought of, for example, as a local supply network that has been built up in each country, and which is available to the multinational to support production. Second, we also assume that there is a fixed factor in the process of transforming the intermediate good into the final good for the local market where it is 
consumed, which generates profit in the country of consumption. Third, the company owns a fixed supply of a factor that can move freely between the two countries. We refer to this factor as managerial skill, but one can also think of it as a stock of intangible assets. The profit generated from access to this asset is mobile between the two countries. Thus, there are three sources of rent, located in the country of initial production, the country of final consumption, and mobile across the two countries.

Allowing for profit to arise from production taking place in each country naturally introduces a transfer of the intermediate good between countries. This permits analysis of the incentives for the multinational to manipulate internal transfer prices under the alternative tax bases. Note that we do not rely on imperfect competition to generate profit, primarily because our main goal is to compare the welfare effects of the alternative tax bases. This comparison is clearer in a model in which there are no inefficiencies in the absence of taxation, as would not be the case in the presence of imperfect competition. ${ }^{6}$

Each of two countries has a representative agent with a utility function of the form:

$$
U=u\left(c_{1}\right)+c_{2}+v(g) ; \quad U^{*}=u^{*}\left(c_{1}\right)+c_{2}^{*}+v^{*}\left(g^{*}\right)
$$

where $c_{1}$ and $c_{2}$ represent consumption of goods 1 and 2 respectively, $g$ is a local public good, and the asterisk denotes the foreign country. In general, the utility functions for good 1 and the public good may differ between the two countries. ${ }^{7}$ The public good is funded entirely by a tax on firms, described below.

\footnotetext{
${ }^{6}$ Imperfect competition would add another element of profit in the model, located in the country of the consumer. The choice between tax bases would then depend on interactions of the tax with pre-existing consumption distortions. Our simpler approach, with no inefficiencies in the absence of tax, is to generate profit in the consumption country through existence of a fixed factor in the process of creating the final good.

7 We assume that there are no income effects in the demand for good 1 to make the model tractable.
} 
In each country there is one unit of an endowment good. Production of one unit of good 2 uses one unit of this endowment, and is therefore characterized by constant returns to scale; we assume this production to be perfectly competitive and hence to generate no profits. Good 2 can be used as a public $(g)$ or private $\left(c_{2}\right)$ good, neither of which is traded, with the remainder supplied as capital, which is assumed to be perfectly mobile across countries. (One may think of the unit endowment as labor, in which case $c_{2}$ represents the household's consumption of leisure.) Hence, the total world supply of capital $(K)$ is

$$
K=\left(1-c_{2}-g\right)+\left(1-c_{2}^{*}-g^{*}\right)=k+k^{*}
$$

where $k$ is the amount of capital used in the home country and $k^{*}$ is the amount used abroad. Note that this expression relating capital to the other uses of good 2 holds on a worldwide basis, rather than on a national basis, as countries may import or export good 2 in the form of capital. In particular, net exports of capital from the home country equal 1 $c_{2}-g-k$, with an analogous expression abroad. There is also trade in the intermediate good, as discussed below.

Good 1 is produced by a single representative multinational, which takes all prices as given. The production of good 1 occurs in two stages. In the first, the multinational produces an intermediate good in both countries, using capital and two additional factors. One is a fixed factor located in the place of production, and might represent, for example, a local supply network that has been built up in each country, and which is available to the multinational to support production. The second is access to a factor, $M$, which is fixed overall but can be used for production in either location, so

$$
M=m+m^{*}
$$


where $m$ is the amount of this factor used in the home country and $m^{*}$ is the amount used abroad. One may think of this factor as managerial skill, or some other firm-specific asset. The key, for our purposes, is that its location is not fixed in either jurisdiction. ${ }^{8}$

We assume that the basic production function used by the multinational is the same in both countries, $f(k, m)$, and that there are decreasing returns to scale because of the local fixed factor. There are no transportation costs, so without taxes the locations of production and consumption are unrelated. Hence,

$$
x_{1}+x_{1}^{*}=f(k, m)+f\left(k^{*}, m^{*}\right)
$$

where $x_{1}$ and $x_{1}^{*}$ are the output from the production processes consumed in the home and foreign country respectively with the home country's exports of the intermediate good equal to $f(k, m)-x_{1}$, with an analogous expression abroad.

The second stage of good-1 production involves making a final product tailored to consumption in the respective countries. One may think of this final production stage as including advertising, distribution, and other activities that take place in the proximity of consumption. This links consumption of good 1 in each country with the basic output sold in that country, according to a common second stage production function, $h(\cdot)$,

$$
c_{1}=h\left(x_{1}\right) ; c_{1}^{*}=h\left(x_{1}^{*}\right)
$$

where $c_{1}$ and $c_{1}^{*}$ are the quantities of final sales of the multinational in each country, and $h(\cdot)$ is assumed to be characterized by decreasing returns to scale.

\footnotetext{
${ }^{8}$ However, in order to allow this source of rent to be mobile between countries, we do assume that this asset cannot be used simultaneously in both countries - i.e., it has no public good aspects within the firm. This corresponds to the fixed management capacity approach in the model of Becker and Fuest (2010), for example. Becker and Fuest also consider the case in which management is a public good within the firm, and Devereux et al (2015) consider a more flexible approach. In Section 5 we consider the effects of changing this assumption, along with other extensions.
} 
Although we model one company, this is equivalent to there being many such companies determining equilibrium prices, with any single company taking output prices as given. Conditional on the consumer price in each country, decreasing returns to scale of $h(\cdot)$ leads to determinate and potentially different values of $x$ in the two countries. If, for example, the home country has a stronger demand for good 1, then this will lead to more consumption and higher rents accruing to the firm associated with consumption there.

The two countries' representative agents own shares $\beta$ and $\beta^{*}\left(\beta+\beta^{*}=1\right)$ of the multinational, and hence its profits $(\pi) .{ }^{9}$ The size of these shares affects the extent to which the incidence of taxes is exported to non-residents. Profits have three components: returns to the fixed factor in basic production, returns to managerial skill, and returns to the fixed factor in final production. The effective locations of these components differ. The return to the basic-production fixed factor is located in the country hosting that factor; the return to managerial skill is mobile, based on the location of managerial skill itself; and the return to the fixed factor in final production is located in the country of consumption. Because governments cannot accurately distinguish these three components separately, they cannot impose non-distortionary profits taxes based on the rents earned in each location.

We now consider the effects of using different types of taxes to raise revenue to finance public goods. Initially, we consider only cases in which both governments adopt the same tax base; in Section 4 we consider the incentives to deviate from a common tax base.

\footnotetext{
${ }^{9}$ Without any loss of generality, one can think of there being several identical multinationals with different ownership shares at home and abroad that aggregate to these shares of domestic and foreign ownership. But the model abstracts from individual portfolio decisions, potentially across firms as well as countries. Taking account of such decisions would bring in a variety of additional factors that might affect ownership shares, production outcomes, and tax exporting, including differential personal taxation on the returns to domestic and foreign portfolio investment and home bias in portfolio allocations. Tax exporting would also be affected by rent sharing between the firm and its workers, as the allocation of rents can be affected by taxation (see, e.g. Arulampalam et al., 2012).
} 


\section{Alternative Tax Regimes}

We consider initially two variants of taxes on cash flows, which fall only on pure profits and which exempt from tax the normal return to capital, $K$. However, we will move on to also consider a source-based capital income tax that falls also on the normal return as well as a cash-flow tax apportioned by sales.

It is useful to begin by characterizing equilibrium in the absence of taxes and public goods. Letting good 2 be the numeraire commodity in both countries (i.e., with a price of 1 in both places, thereby also normalizing the exchange rate to 1), conditions for utility maximization are:

$$
u^{\prime}\left(c_{1}\right)=\frac{p_{1}}{p_{2}}=p_{1} ; \quad u^{*^{\prime}}\left(c_{1}^{*}\right)=\frac{p_{1}^{*}}{p_{2}^{*}}=p_{1}^{*},
$$

and profits of the multinational are:

$$
\pi=p_{1} c_{1}+p_{1}^{*} c_{1}^{*}-K=u^{\prime}\left(c_{1}\right) h\left(x_{1}\right)+u^{*^{\prime}}\left(c_{1}^{*}\right) h\left\{f(k, m)+f(K-k, M-m)-x_{1}\right\}-K
$$

where $\pi$ equals the sum of profits generated by the first production stages in both countries (the difference between $f(k, m)$ and the costs of $k$ and $m$ and likewise abroad), those generated by the second stage ( $h\left(x_{1}\right)$ minus the cost of $x_{1}$ and likewise abroad), and those generated by $m$ and $m^{*}$. Note that while these components are conceptually distinct, they are not distinctly observable because of the absence of transactions for the different production stages within the firm.

Maximizing profit with respect to $k, m, K$, and $x_{1}$ yields the firm's first-order conditions: 


$$
\begin{array}{ll}
k: & f_{1}(k, m)=f_{1}\left(k^{*}, m^{*}\right) \\
m: & f_{2}(k, m)=f_{2}\left(k^{*}, m^{*}\right) \\
K: & u^{*^{\prime}}\left(c_{1}^{*}\right) h^{\prime}\left(x_{1}^{*}\right)=\frac{1}{f_{1}\left(k^{*}, m^{*}\right)} \\
x_{1}: & u^{\prime}\left(c_{1}\right) h^{\prime}\left(x_{1}\right)=u^{*^{\prime}}\left(c_{1}^{*}\right) h^{\prime}\left(x_{1}^{*}\right)
\end{array}
$$

where $f_{1}$ is the marginal product of capital and $f_{2}$ is the marginal product of managerial skill. Conditions (3.3) and (3.4) call for production efficiency, with the marginal product of capital equal across the two countries, and also the marginal product of managerial skill equal across the two countries. Condition (3.5) calls for setting marginal revenue equal to marginal cost. Condition (3.6) implies that marginal revenues, in this case equal to marginal consumer valuation, should be independent of consumption location.

Finally, the household budget constraint becomes (with the equivalent abroad):

$$
u^{\prime}\left(c_{1}\right) c_{1}+c_{2}=1+\beta\left(u^{\prime}\left(c_{1}\right) c_{1}+u^{*^{\prime}}\left(c_{1}^{*}\right) c_{1}^{*}-K\right)
$$

We now consider alternative forms of taxation, used to finance the public good.

\subsection{Source-based cash-flow tax}

We begin with a cash-flow tax based on the source principle, the standard approach of the existing international tax system. It is well-known that a traditional source-based capital income tax encourages shifting of both real activities and accounting profits to lower-tax countries. We show below that these two distortions remain under a cash-flow tax, and analyze the interactions between them.

Since cash-flow taxes fall only on profit and there is no profit in the competitive sector 2 , then there would be no taxes in this sector, so $p_{2}=1$. Hence, the prices of good 1 in 
the two countries are governed by expression (3.1). Define $e$ to be gross exports of the intermediate good from the home country plant to the foreign country plant at price $q$ and $e^{*}$ to be gross exports of the intermediate good from the foreign country plant to the home country plant at price $q^{*}$, where $q$ and $q^{*}$ are the multinational company's internal transfer prices used for tax purposes. Then the total profit in the home country (from both stages of good-1 production) is $(1-t)\left\{p_{1} c_{1}+q e-q^{*} e^{*}-k\right\}$, and total profit in the foreign country is $\left(1-t^{*}\right)\left\{p_{1}^{*} c_{1}^{*}+q^{*} e^{*}-q e-k^{*}\right\}$. Total after-tax profit is:

$$
\pi=\left(p_{1} c_{1}-k\right)(1-t)+\left(p_{1}^{*} c_{1}^{*}-k^{*}\right)\left(1-t^{*}\right)+\left(q^{*} e^{*}-q e\right)\left(t-t^{*}\right) .
$$

Conditional on the two countries' production and consumption, net exports $\left(e-e^{*}\right)$ are determined, but not gross exports. Offsetting unit increases in $e$ and $e^{*}$ lead to a net increase in after-tax profits of $\left(q^{*}-q\right)\left(t-t^{*}\right)$.

As we discuss below, it may be open to the company to manipulate these internal prices to reduce its tax liability. But it is useful to consider as a benchmark the price that would arise if transactions were among independent companies. Imagine that the multinational has four independent, price-taking plants, two in each country. In each case plant A uses $k$ to produce $x$ and plant B uses $x$ to produce the final good $c$. Consider the case where there is no international trade, in which case the profits of the two home country plants are $\pi_{A}=(1-t)\{q f(k, m)-k\}$ and $\pi_{B}=(1-t)\left\{p_{1} h\left(x_{1}\right)-q x_{1}\right\}$. Plant A chooses $k$ to maximize its profit and plant B chooses $x_{1}=f(k, m)$ to maximize its profit. What value of $q$ would yield the same outputs as in the case where these two plants were combined, i.e., the value of $k=\hat{k}$ for which $p_{1} h^{\prime}\left(x_{1}\right) f_{1}(\widehat{k}, m)=1$ ? The answer is $q=1 / f_{1}(k, m)$, which is the marginal cost of producing $x_{1}$. That is, if the transfer price is set equal to the marginal 
cost of plant $A$, then outputs would not be affected by splitting the home plant into two parts. The same applies to the case in which the intermediate good is exported, and holds even in the presence of the cash-flow tax analyzed here, so in addition we have as a benchmark $q^{*}=1 / f_{1}\left(k^{*}, m^{*}\right) .10$

If transfer prices are set equal to marginal $\operatorname{cost}^{11}$ (which will then turn out to be equal across the two countries, i.e., $q=\frac{1}{f_{1}^{*}}=\frac{1}{f_{1}}$ ), the first order conditions are:

$$
\begin{aligned}
& k: f_{1}=f_{1}^{*} \\
& m: f_{2}(1-t)=f_{2}^{*}\left(1-t^{*}\right) \\
& K: \quad p_{1} h^{\prime}=\frac{1}{f_{1}^{*}} \\
& x_{1}: \quad p_{1}^{*} h^{* \prime}=p_{1} h^{\prime}
\end{aligned}
$$

where for ease of notation we have dropped the arguments for the functions $h($.$) and f($. and replaced the derivatives of the utility functions with price terms.

In this instance, unlike under source-based capital income taxes, there is no distortion to the marginal condition for capital because the normal return to capital is taxexempt under a cash-flow tax. ${ }^{12}$ Likewise, there is no distortion in the second stage of production, where consumption rents are generated. But returns to managerial skill are taxed where this factor is used in production, so the firm is deterred from using it where the tax rate is high. That is, the source-based cash-flow tax distorts the location of the mobile factor of production; this is akin to the results in VAT literature that an origin-based

\footnotetext{
${ }^{10}$ As discussed by Hirshleifer (1956), setting the internal transfer price equal to marginal cost is also consistent with the optimal behaviour of a single firm seeking to decentralize profit maximization among its separate units.

${ }^{11}$ This would be true, for example, in the limiting case discussed below in which the interval $\left[q_{L}, q_{U}\right]$ collapses to the firm's marginal cost.

${ }^{12}$ Taxes will still affect the allocation of capital indirectly, through the distortion of the location choice of $M$, which in turn affects the marginal product of capital in the two locations.
} 
VAT distorts production where there is factor mobility (Lockwood, 2001). That is, a greater share of both $M$ and $K$, and hence production is allocated to the low tax country. This allocation does not depend on demand parameters. However, the direction and size of exports does depend on demand. For example, it is possible that the strength of demand is so much higher in the low tax country that some of the production in the high tax is nevertheless exported to the low tax country.

In the more general case, the multinational may exploit the absence of an arm's length price to manipulate its transfer prices in order to shift profit between the two countries. But even with considerable latitude in its choice of transfer prices $q$ and $q^{*}$, we assume that tax enforcement is sufficiently effective that the firm cannot choose different values for the two, for example exporting at a high price from the low-tax country and then importing the same good back from the high-tax country at a low price. This means that the firm can gain no benefit from cross-hauling, so without loss of generality we can assume that at most one country exports. That is, with $q=q^{*}$ in expression (3.8), there are four possible regimes:

$\begin{array}{llll}\text { Case A: } & e>0, e^{*}=0 \text { and } t<t^{*} & \text { Case B: } & e=0, e^{*}>0 \text { and } t>t^{*} \\ \text { Case C: } & e>0, e^{*}=0 \text { and } t>t^{*} & \text { Case D: } & e=0, e^{*}>0 \text { and } t<t^{*}\end{array}$

In cases A and B, the high-tax country imports the intermediate good, so the firm will wish to maximize $q$. In cases $\mathrm{C}$ and $\mathrm{D}$, the high-tax country is exporting, and the firm will wish to minimize $q$.

As modeling the firm's choice of its transfer price is potentially quite complex, we analyze behavior under the simplifying assumption that there is some range of observed 
comparable prices, exogenous from the firm's perspective, which would be acceptable to the tax authorities of both countries. The firm can choose prices within this range without cost, but beyond this range it would be challenged by tax authorities to provide additional documentation to justify its chosen price and might also face negotiation between the two tax authorities. ${ }^{13}$ This would introduce high costs that the firm would prefer to avoid, so that it will never find it optimal to choose a transfer price outside the observed range. That is, we assume that the firm chooses the transfer price $q \epsilon\left[q_{L}, q_{u}\right]$ that maximizes profits. Specifically, to shift profit to the lower taxed country, in cases A and B the firm chooses a high $q=q_{u}$ and in cases $\mathrm{C}$ and $\mathrm{D}$ it chooses a low $q=q_{L}$.

Note also that in all four cases, net imports are $e^{*}-e=x_{1}-f(k, m)$. This generates general first order conditions based on optimization of profits as given in (3.8) as follows:

$$
\begin{array}{ll}
k: & p_{1}^{*} h^{*^{\prime}}\left(f_{1}-f_{1}^{*}\right)\left(1-t^{*}\right)+\left(1-q f_{1}\right)\left(t-t^{*}\right)=0 \\
m: & p_{1}^{*} h^{*^{\prime}}\left(f_{2}-f_{2}^{*}\right)\left(1-t^{*}\right)-q f_{2}\left(t-t^{*}\right)=0 \\
K: \quad & p_{1}^{*} h^{*^{\prime}}=\frac{1}{f_{1}^{*}} \\
x_{1}: & (1-t)\left(p_{1} h^{\prime}-q\right)-\left(1-t^{*}\right)\left(p_{1}^{*} h^{* \prime}-q\right)=0
\end{array}
$$

(where the value of $q$ depends on the case, as described above.)

More generally, the opportunity to manipulate transfer prices not only benefits the firm, but also further distorts its production decisions. Consider first Case A, with $t<t^{*}$, where the home plant is exporting, and where the firm wishes to maximize $q$. From (3.9')

\footnotetext{
${ }^{13}$ Becker and Davies (2014) develop a more detailed model of transfer pricing based on this approach. A common alternative approach of assuming convex costs of transfer pricing manipulation would significantly complicate the analysis. Also, recent evidence (Habu, 2017) suggests that many multinational firms pay no tax at all in some jurisdictions in which they operate, which would appear to be inconsistent with convex costs of shifting profit.
} 
$q=q_{u}>\frac{1}{f_{1}}$ implies that $f_{1}<f_{1}^{*}$. That is, with transfer pricing manipulation, the firm shifts production from the foreign country to the home country, reducing $f_{1}$ and increasing $f_{1}^{*}$. Relative to the marginal cost pricing case, in this case one can also show that $q>\frac{1}{f_{1}}$ would also increase $f_{2}^{*}-f_{2}$, pushing more intellectual property to the home country. Thus, exports from the home country increase. By symmetry, the same result, that exports from the low-tax country increase, will hold for Case B. Now consider Case C, with $t>t^{*}$, where again the home firm is exporting, but now the firm wishes to minimize $q$. From (3.9'), $q=$ $q_{L}<\frac{1}{f_{1}}$ implies that $f_{1}<f_{1}^{*}$. That is, with transfer pricing manipulation, production is again shifted from the foreign country to the home country, reducing $f_{1}$ and increasing $f_{1}^{*}$. Relative to the marginal cost pricing case, in this case $q<\frac{1}{f_{1}}$ would reduce $f_{2}-f_{2}^{*}>0$, again pushing more intellectual property to the home country. Thus, transfer-pricing manipulation again increases exports from the home country. By symmetry, the same result, that exports from the high-tax country increase, will hold for Case D. ${ }^{14}$

Thus, we have the interesting result that, whether the high-tax or low-tax country exports, the ability to manipulate transfer prices causes the firm to adjust the location of production to the country from which it exports. Contrary to a common view on the subject, the firm's ability to manipulate transfer prices does not necessarily lead to a shift in production to the low-tax country, unless the firm would export from the low-tax country in the absence of transfer pricing manipulation. Certainly, by expression (3.10), other things being equal the firm already will have the tendency to locate one of its production

\footnotetext{
${ }^{14}$ It is possible that in Cases $\mathrm{C}$ and $\mathrm{D}$, the effects of transfer pricing manipulation can shift so much production to the high-tax exporting country that more production is undertaken in the high tax country.
} 
factors, managerial skill, in the low-tax country, increasing that country's production level and making it more likely to export. But the low-tax country might also have a stronger demand for good 1, and so still might import.

This result - that transfer-pricing manipulation could sustain production in a hightax country - is relevant when one considers the potential effects of policies to tighten transfer-pricing rules, as recommended by the OECD (2015), which in our framework can be interpreted as a narrowing of the size of the interval $\left[q_{L}, q_{u}\right]$. While such an approach would result in closer alignment between the income generated and the income reported in each location, it could also reduce the level of income generated in a high-tax country.

Also of note is how the production distortions due to transfer pricing manipulation interact with the basic ones of the source-based system. The capital-allocation distortion is clearly worsened by transfer pricing manipulation, since there is no other distortion present on this margin. However, the effect on the managerial skill margin could go either way. In particular, in cases $C$ and $D$, where transfer pricing manipulation leads the high-tax country to increase its exports, this pushes managerial skill to the high-tax country, thereby offsetting the initial distortion observed in expression (3.10). Overall, then, transfer pricing manipulation has an ambiguous impact on welfare, as discussed in Hong and Smart (2010).

These effects can be illustrated using a simple numerical simulation approach which is set out in Appendix E. This applies Cobb-Douglas functional forms to all production and utility functions and makes specific assumptions for parameter values. The effects of transfer pricing manipulation in a simple simulation are shown in Table 1 , where it is assumed that tax rates are $t=60 \%$ and $t^{*}=40 \%$. The first three columns show the values of production and exports in each country in the absence of any transfer pricing 
manipulation, so that $q=1 / f_{1}=1 / f_{1}^{*}$. The next three columns show values where transfer prices are manipulated by $10 \%$, so that $q=0.9 / f_{1}^{i}$ or $1.1 / f_{1}^{i}$, depending on the incentive to underprice or overprice exports, where $f_{1}^{i}=f_{1}\left(f_{1}^{*}\right)$ if the home (foreign) country is the exporter in equilibrium.

Table 1. Numerical Simulation to Illustrate Impact of Transfer Pricing Manipulation

\begin{tabular}{|c|c|c|c|c|c|c|}
\hline & \multicolumn{2}{|c|}{ Without Transfer Pricing Manipulation } & \multicolumn{3}{|c|}{ With Transfer Pricing Manipulation } \\
\hline $\begin{array}{c}\text { Symmetric } \\
\text { production } \\
\text { and } \\
\text { preference } \\
\text { parameters }\end{array}$ & $\begin{array}{c}\text { Lower } \\
\text { preference } \\
\text { for good 1 } \\
\text { in foreign } \\
\text { country }\end{array}$ & $\begin{array}{c}\text { Lower } \\
\text { preference } \\
\text { for good 1 } \\
\text { in home } \\
\text { country }\end{array}$ & $\begin{array}{c}\text { Symmetric } \\
\text { production } \\
\text { and } \\
\text { preference } \\
\text { parameters }\end{array}$ & $\begin{array}{c}\text { Lower } \\
\text { preference } \\
\text { for good 1 } \\
\text { in foreign } \\
\text { country }\end{array}$ & $\begin{array}{c}\text { Lower } \\
\text { preference } \\
\text { for good 1 } \\
\text { in home } \\
\text { country }\end{array}$ \\
\hline$k$ & 0.22 & 0.15 & 0.15 & 0.18 & 0.13 & 0.17 \\
\hline$k^{*}$ & 0.49 & 0.33 & 0.33 & 0.54 & 0.36 & 0.31 \\
\hline$m$ & 0.23 & 0.23 & 0.23 & 0.19 & 0.19 & 0.26 \\
\hline$m^{*}$ & 0.77 & 0.77 & 0.77 & 0.81 & 0.81 & 0.74 \\
\hline$x$ & 1.96 & 2.70 & 0.63 & 2.02 & 2.75 & 0.61 \\
\hline$x^{*}$ & 1.96 & 0.63 & 2.70 & 1.89 & 0.59 & 2.75 \\
\hline$e$ & 0 & 0 & 0.40 & 0 & 0 & 0.53 \\
\hline$e^{*}$ & 0.75 & 1.68 & 0 & 0.98 & 1.86 & 0 \\
\hline
\end{tabular}

Note. Values shown in the table are the levels of the domestic and foreign $\left({ }^{*}\right)$ capital stock $(k)$, managerial skill $(m)$, intermediate goods purchases $(x)$ and exports $(e)$. They are derived from the simulation model described in Appendix E, which uses Cobb Douglas functional forms for both production and utility, with aggregate managerial skill and each country's labor endowment equal to 1 . Tax rates are $t=60 \%$ and $t^{*}=40 \%$.

The first column within each group shows the case in which all production and utility function parameters are common across countries. In the absence of transfer price manipulation, then from (3.10) the higher home country tax rate implies that $f_{2}>f_{2}^{*}$, which is achieved by having a higher allocation of managerial skill to the foreign country, $m<m^{*}$. From (3.9), $f_{1}=f_{1}^{*}$, which, given $m<m^{*}$, requires $k<k^{*}$, so that there is also a higher allocation of capital to the foreign country. Given equality in preferences, though, 
$x=x^{*}$, which requires $e^{*}>0$ and $e=0$. This is therefore an example of Case B. Allowing for transfer price manipulation, the firm would overprice exports from the foreign country. This option leads to a further shift of $M$ and $K$ to the foreign country (and also a small rise in K). As a consequence, transfer price manipulation also raises $e^{*}$. Transfer price manipulation also induces a rise in $x$ and a fall in $x^{*}$, even though preferences are symmetric, as a consequence of the firm's incentive to export to the importing country.

Now suppose that there is a lower preference for good 1 in the foreign country only. Without transfer price manipulation, this reduction in demand reduces total $K$. There is a similar proportionate allocation of $K$ and $M$ between the two countries as in the symmetric case. But since $x^{*}$ is lower due to the reduced demand, more of the output from the foreign country is exported, i.e. $e^{*}$ rises. If the lower preference for good 1 is instead in the home country, there is no difference in the first stage production because of the absence of trade costs. In this case, $x$ is lower due to the reduced demand, which implies that the direction of the export of the intermediate good changes, with $e>0$ and $e^{*}=0$. In both cases of asymmetric preferences, transfer price manipulation again shifts both production factors to the exporting country and shifts purchases of the intermediate good to the importing country. This occurs even when this is the high-tax, home country.

\subsection{Destination-based cash-flow tax}

We now consider a cash-flow tax with the tax liability in each country determined as domestic sales less domestic expenses, as under a VAT. More precisely, we consider the same tax base as the source-based tax analyzed in Section 3.1, but with the difference that 
we add border adjustments along the lines of VAT, so that exports are not taxed, but imports are taxed.

Consider first the tax treatment of competitive sector 2 . In the absence of any trade in good 2, in the form of capital, profits are zero and tax from this sector is zero. But with trade then an import of capital would be subject to the import tax at rate $t$ or $t^{*}$. The price of the domestically produced good 2 must be the same as for imported goods. The tax liability in sector 2 and on imports together is:

$$
T_{2}=t\left\{p_{2}\left(c_{2}+k+g\right)-w\right\}
$$

where $w$ is the producer price of the endowment. If $\left(c_{2}+k+g\right)<1$ then the home country exports capital and its tax is negative, as it receives relief for its expenses measured by the producer price of the endowment: $T_{2}<0$. If $\left(c_{2}+k+g\right)>1$ then then it imports capital, and it pays a positive tax on the import, $T_{2}>0$.

If $\left(c_{2}+k+g\right)<1$, the post-tax zero-profits condition is:

$$
\pi_{2}=(1-t)\left\{p_{2}\left(c_{2}+k+g\right)-w\right\}+\left(1-t^{*}\right) p_{2}^{*}\left(1-c_{2}-k-g\right)=0
$$

which is solved by $p_{2}=w=1 /(1-t)$ and $p_{2}^{*}=1 /\left(1-t^{*}\right)$. That is, continuing to assume that the good 2, in the form of capital, is traded at a price of 1 , the consumer price and the domestic producer price of good 2 are grossed up by $(1-t)$ in the home country and (1$\left.t^{*}\right)$ in the foreign country. The goods exported to the foreign country are taxed at rate $t^{*}$, and so are the same price as domestically produced goods in that country. Therefore,

$$
u^{\prime}\left(c_{1}\right)=\frac{p_{1}}{p_{2}}=(1-t) p_{1} ; \quad u^{*^{\prime}}\left(c_{1}^{*}\right)=\frac{p_{1}^{*}}{p_{2}^{*}}=\left(1-t^{*}\right) p_{1}^{*}
$$


If $c_{2}+k+g>1$, post-tax profit is zero, but the price of good 2 must reflect the import tax and so is again grossed up in the same way.

After tax profits in sector 1 (and hence overall as well) are:

$$
\pi=(1-t)\left\{p_{1} c_{1}-p_{2} k\right\}+\left(1-t^{*}\right)\left\{p_{1}^{*} c_{1}^{*}-p_{2}^{*}(K-k)\right\}=u^{\prime}\left(c_{1}\right) c_{1}+u^{*^{\prime}}\left(c_{1}^{*}\right) c_{1}^{*}-K
$$

This expression is the same as (3.2) in the absence of tax, which implies that the tax has no effect on firm behavior.

The household budget constraint (with an equivalent condition for the foreign country) is:

$$
\begin{aligned}
& p_{1} c_{1}+p_{2} c_{2}=w+\beta\left(u^{\prime}\left(c_{1}\right) c_{1}+u^{*^{\prime}}\left(c_{1}^{*}\right) c_{1}^{*}-K\right) \\
\Rightarrow & u^{\prime}\left(c_{1}\right) c_{1}+c_{2}=1+(1-t) \beta\left(u^{\prime}\left(c_{1}\right) c_{1}+u^{*^{\prime}}\left(c_{1}^{*}\right) c_{1}^{*}-K\right) .
\end{aligned}
$$

This expression makes it clear that the destination-based tax is equivalent to a tax on the pure profits received by domestic residents. Note that if one thinks of good 2 as leisure, then the lack of distortion here can also be thought of as relating to the fact that the destination-based cash-flow tax excludes labor from the tax base, unlike a standard VAT.

\section{Incentives for Tax Competition and Tax Reform}

We have discussed the effects on firm behavior of different tax systems, but a critical question is what tax systems, and tax rates, countries have incentives to adopt. The incentives for tax competition through rate reductions under source-based income taxation are well established both theoretically and empirically. But what are the incentives for competition in cash-flow taxes via changes in tax systems? Ideally, one would like to 
identify each country's optimal strategy in terms of tax system and tax rate, but this is generally not possible without specific functional form and parameter assumptions, such as we provide in Appendix E. Still, we can learn a lot by considering incentives for different marginal policy changes. Specifically, starting from an assumed equilibrium with common tax systems, we can ask whether the home country would wish to make an incremental substitution of an alternative tax system, holding fixed the other country's tax policy.

We consider the incremental substitution of a new tax for the old, keeping fixed the level of public goods spending and hence tax revenue. ${ }^{15}$ Under any tax system, a government seeking to maximize the representative resident's utility, as given in expression (2.1), with respect to the tax rate, $t$, will have as a first-order condition that the derivative of the resident's indirect utility function with respect to $t$ equals 0 . That is, incorporating the government's budget constraint that $g=T$, the government's first-order condition is:

$$
\frac{d y}{d t}-c_{1} \frac{d p_{1}}{d t}-c_{2} \frac{d p_{2}}{d t}+v^{\prime}(g) \frac{d T}{d t}=0 \Rightarrow g=v^{\prime}-1\left(-\frac{d Y / d t}{d T / d t}\right)
$$

where $y$ is the resident's nominal income - its share of the multinational's after-tax profits, $\beta \pi-$ and $d Y / d t$ may be interpreted as the change in real income due to an increase in $t$, resulting from the direct change in nominal income plus the change in purchasing power due to price changes:

$$
\frac{d Y}{d t}=\frac{d y}{d t}-c_{1} \frac{d p_{1}}{d t}-c_{2} \frac{d p_{2}}{d t}=\beta \frac{d \pi}{d t}-c_{1} \frac{d p_{1}}{d t}-c_{2} \frac{d p_{2}}{d t} .
$$

\footnotetext{
${ }^{15}$ By the envelope theorem, changes in public spending would have no first order effects on welfare, assuming that the level of spending was initially optimal.
} 
The term $-\frac{d Y / d t}{d T / d t}$ measures the marginal cost of public funds, accounting for the full cost, from the country's perspective, of raising an extra dollar of revenue. When we consider incremental changes that keep overall revenue fixed, a necessary and sufficient condition for increasing the real income and hence the well-being of the country's representative agent will be that the policy change reduces the marginal cost of public funds. That is, suppose we reduce the tax rate, denoted $s$, under one system and increase the tax rate, denoted $z$, under an alternative system. This would generate an increase in welfare if the marginal cost of public funds were higher under the first system, that is, if:

$$
-\frac{d Y / d z}{d T / d z}<-\frac{d Y / d s}{d T / d s}
$$

Two factors will play a role in determining whether this condition is met. First, as in a domestic context, the marginal cost of public funds will be higher as the deadweight loss from taxation is higher. This factor will encourage a shift to less distortionary taxes. Second, taxes may differ in the extent to which they can be exported - that is borne by nonresidents - which increases the real income of domestic residents.

\subsection{The choice between source-based and destination-based cash-flow taxes}

Since source-based taxes are a standard form of taxation, we begin by asking whether an individual country would have an incentive to move to a destination base, starting from an equilibrium in which each country relies only on a source-based cash-flow tax. Our analysis identifies factors that make reliance on a destination-based tax more or less likely, although closed form solutions are not generally available. To get a sense of what actual outcomes might look like, we provide explicit numerical solutions for the Cobb- 
Douglas version of the model described and used in Section 3, although without transfer pricing manipulation, given the greater complexity of solving for equilibrium with twodimensional government reaction functions.

To begin, we assume that the two countries have source-based cash-flow taxes at rates $s$ and $s^{*}$. The home country then makes a marginal switch to a destination-based cashflow tax at rate $z$, holding tax revenue constant. However, so that we do not have to keep track of associated prices changes, we assume for simplicity that the destination-based tax is implemented in its equivalent form of a pure profits tax, at rate $z$, on the home country's share of profits (see expression (3.17)). In this case, the tax does not affect $p_{2}$ and hence expression (3.1) holds.

From (4.2), the effects of changes in the two tax rates on real income are:

$$
\frac{d Y}{d z}=\beta \frac{d \pi}{d z}-c_{1} \frac{d p_{1}}{d z} ; \text { and } \frac{d Y}{d s}=\beta \frac{d \pi}{d s}-c_{1} \frac{d p_{1}}{d s}
$$

since the price of good 2 equals 1 under both tax systems. In this case, $p_{1}=u^{\prime}\left(c_{1}\right)$. Since an increase in $z$ is non-distortionary, its only behavioral impact will be to reduce $g$ and $c_{2}$; prices, consumption of good 1 and capital are all unaffected. As a result,

$$
\frac{d Y}{d z}=-\beta \pi=-\frac{d T}{d z}
$$

and so the left-hand side of condition (4.3) is equal to 1 and therefore (4.3) reduces to $\frac{d Y}{d s}+$ $\frac{d T}{d s}<0$; that is, the increase in real income from reducing the source-based tax must be larger than the decline in revenue. Put another way, the marginal cost of public funds in the 
initial equilibrium must exceed 1 , since there is neither tax exporting nor distortion under the destination-based tax.

To identify the effects of a change in the source-based tax, we first specify the profit of the multinational as in (3.8), as

$$
\pi=\left[\left(p_{1} c_{1}-k\right)(1-s)+\left(p_{1}^{*} c_{1}^{*}-k^{*}\right)\left(1-s^{*}\right)-q\left(e-e^{*}\right)\left(s-s^{*}\right)\right]
$$

The effect of a change in the source-based tax rate on real income is then, from (4.2):

$$
\frac{d Y}{d s}=\beta\left\{-p_{1} c_{1}+k-q\left(e-e^{*}\right)+(1-s) c_{1} \frac{d p_{1}}{d s}+\left(1-s^{*}\right) c_{1}^{*} \frac{d p_{1}^{*}}{d s}\right\}-c_{1} \frac{d p_{1}}{d s},
$$

where other terms in $d \pi / d s$ are zero by the envelope theorem. Total tax levied is

$$
T=z \beta \pi+s\left(p_{1} c_{1}-k+q\left(e-e^{*}\right)\right) .
$$

Using $c_{1}=h\left(x_{1}\right), e-e^{*}=f(k, m)-x_{1}$ and $\frac{d f}{d s}=f_{1} \frac{d k}{d s}+f_{2} \frac{d m}{d s}$, this implies that

$$
\frac{d T}{d s}=p_{1} c_{1}-k+q\left(e-e^{*}\right)+s\left(c_{1} \frac{d p_{1}}{d s}+\left(p_{1} h^{\prime}-q\right) \frac{d x_{1}}{d s}-\left(1-q f_{1}\right) \frac{d k}{d s}+q f_{2} \frac{d m}{d s}\right)
$$

Combining these expressions, rearranging and using $\beta+\beta^{*}=1$ and $p_{1} h^{\prime}=1 / f_{1}$ (from $\left.\left(3.11^{\prime}\right)^{16}\right)$, we can write the condition for welfare improvement as:

$$
\begin{aligned}
-s\left(\frac{f_{2}}{f_{1}} \frac{d m}{d s}\right)- & s\left(q-\frac{1}{f_{1}}\right)\left(\frac{d\left(e-e^{*}\right)}{d s}\right) \\
& >\beta^{*}\left[p_{1} c_{1}+q\left(e-e^{*}\right)-k\right]+\beta\left(1-s^{*}\right) c_{1}^{*} \frac{d p_{1}^{*}}{d s}-\beta^{*}(1-s) c_{1} \frac{d p_{1}}{d s}
\end{aligned}
$$

\footnotetext{
${ }^{16}$ While (3.11') refers to the foreign country, symmetry implies that it holds for the home country as well.
} 
To interpret this condition, consider first the three terms on the right-hand side. All reflect the division of profits between the two countries, and account for the reduction in tax exporting in shifting to the destination-based tax, under which there is no tax exporting. The first term is the direct incidence on foreign shareholders of a change in the tax rate on domestic profits. Lowering $s$ reduces this tax exporting effect. The second and third terms account for further shifting through induced changes in domestic and foreign output prices. These terms have different signs; an increase in the foreign consumer price benefits domestic residents by increasing their share of world-wide profits, while an increase in the domestic consumer price lowers domestic consumers' real income to the extent that the resulting domestic profits go to foreigners. Assuming that lowering $s$ reduces consumer prices, these two terms are, respectively, positive and negative, the first reducing the attractiveness of a shift from source-based taxation and the second increasing it.

The terms on the left-hand side of (4.10) are associated with the distortions of source-based taxation that a shift to a destination-based tax lessens. The first, which is positive, represents the increased revenue generated from attracting managerial capital by reducing the source-based tax. The second adjusts the change in tax revenue associated with a change in exports for the fact that revenue is based on the reported transfer price rather than marginal cost. Assuming that net exports fall with an increase in $s$ (i.e., $\frac{d\left(e-e^{*}\right)}{d s}<$ 0 ), ${ }^{17}$ this term will also be positive (making adoption of the tax reform more likely) if the transfer price is overstated, i.e., in the "normal" cases A and B in which the low-tax country is the exporting country. In case A, the low-tax domestic country, by lowering its source-

\footnotetext{
${ }^{17}$ This is shown in Appendix A for the case where the transfer price is set at marginal cost, preferences are the same in the two countries and the tax rates are initially equal.
} 
based tax, increases its gain via transfer pricing by expanding its exports. In Case B, the high-tax domestic country, by lowering its source-based tax, reduces its loss via transfer pricing by shrinking its imports. ${ }^{18}$ Thus, both terms take the familiar form of marginal deadweight loss expressions, equal to a tax wedge multiplied by the change in quantity to which the wedge applies, although in this case the distortions are measured in terms of the welfare of the home country only.

Note that in cases $\mathrm{C}$ and $\mathrm{D}$, where the high-tax country exports, the second term on the left-hand side of (4.10) will be negative, still assuming that net exports fall with an increase in $s$, and hence the presence of transfer-pricing manipulation reduces the country's likelihood of shifting away from a source-based tax. The intuition for this result is that, as discussed in Section 3, firms will export more when they can manipulate transfer prices to take advantage of a tax differential, even when exporting from a high-tax country. This promotes production in the high-tax country, and hence lessens the real behavioral response away from production there that would otherwise occur. Thus, for a high-tax exporting country (case C) or a low-tax importing country (case D) reducing its sourcebased tax, there is a smaller gain in domestic production activity.

For most of our remaining discussion, we will consider the special case in which countries have common preferences for good 1, equal ownership, and equal initial tax rates. With equal tax rates, production will be the same in the two countries, and with equal preferences so will consumption of good 1 (since there are no income effects), so there will

\footnotetext{
${ }^{18}$ As discussed in the Introduction, one may think of the incentive to shift managerial capital as reflecting a failure of transfer pricing, in the sense that moving the factor from one country to the other requires no payment by the second country to the first. Under this interpretation, each factor on the left hand-side of expression (4.10) equals a transfer-pricing wedge (respectively, the marginal revenue product of managerial capital, since $1 / f_{1}$ is the arm's length price of the intermediate good, and the transfer-pricing gap associated with trade in intermediate goods) multiplied by the applicable tax rate, $s$, and the associated behavioral response to the tax reform being considered.
} 
also be no net exports of good 1, and hence no incentive initially for a deviation from marginal-cost transfer pricing. For this case, Appendix A shows that consumer prices will be the same in the two countries, so that (4.10) reduces to:

$$
-s\left(\frac{f_{2}}{f_{1}} \frac{d m}{d s}\right)>\beta^{*}\left(p_{1} c_{1}-k\right)
$$

(where in this case $\beta^{*}=1 / 2$.) As both terms in (4.11) are positive, there remains a trade-off between attracting managerial capital and the direct tax exporting effect. However, a higher initial value of $s$ would, ceteris paribus, make the shift more likely, with the nonlinearity of the efficiency term causing this effect to dominate the tax exporting term.

As this last point highlights, the attractiveness of a shift away from source-based taxation depends crucially on the initial source-based tax rate, $s$. For very low tax rates, distortions are small, and we would expect tax exporting to dominate. To illustrate this point, consider the alternative case in which both countries start with a destination-based tax and contemplate the introduction of a source-based tax. In this case, it is straightforward to show that conditions (4.10) and (4.11) still hold, evaluated at $s=0$. The terms on the left-hand sides of both expressions disappear - there is no first-order deadweight loss starting from a zero tax rate - and a sufficient condition for introducing the source-based tax is that tax exporting increases with the tax, which must be the case in the symmetric initial equilibrium for which (4.11) applies. Thus, the appeal of the sourcebased tax depends on how high the rate is, and it is quite possible that countries will wish to shift away from a high source-based cash-flow tax but not to eschew it entirely.

We can again illustrate these effects using the numerical simulation model described in Section 3.1 and set out more fully, including parameter choices, in Appendix E. 
To reflect the discussion above, we solve for two Nash equilibria, one in which the two countries are constrained to use only source-based cash-flow taxes, and the other in which countries choose source- and destination-based cash-flow taxes simultaneously, We consider only symmetric cases, in which all parameter values are the same for both countries. Table 2 shows the resulting (equal) equilibrium tax rates.

Table 2. Symmetric Nash Equilibrium Tax Rates

\begin{tabular}{|l||c||c|c|}
\hline & $\begin{array}{c}\text { Source-Based } \\
\text { Rate Only }\end{array}$ & $\begin{array}{c}\text { Source- } \\
\text { Based Rate }\end{array}$ & $\begin{array}{c}\text { Destination- } \\
\text { Based Rate }\end{array}$ \\
\hline Base case & .60 & .57 & .30 \\
\hline$k$ and $m$ more productive & .54 & .49 & .44 \\
\hline$k$ more productive; $m$ less productive & .64 & .62 & .27 \\
\hline$x$ more productive; lower good-1preference & .56 & .44 & 1.00 \\
\hline$x$ less productive; higher good-1preference & .70 & .70 & 0 \\
\hline
\end{tabular}

Note. Tax rates shown in the table are for the cases in which countries use only source-based taxes (column 1) and when they choose source- and destination-based taxes simultaneously (columns 2 and 3), for different assumptions regarding first- and second-stage productivity and preference for the final good supplied by the multinational firm.

The first row of the table shows results for the base case in which the Cobb-Douglas production parameters for $k$ and $m$ are equal. Here, the two countries choose source-based tax rates of 60 percent, but when adding destination-based taxes to their set of available instruments they reduce their source-based tax rates and raise some of their revenue using a destination-based tax. In the second row, both production parameters are higher, meaning that the share of income from the first stage going to the fixed local production factor is lower and the share going to mobile managerial skill is higher. Both changes make 
source-based taxation more distortionary, which results in a lower equilibrium tax rate of .54 when only source-based taxation is used. Further, the greater distortion under sourcebased taxation makes destination-based taxes relatively more attractive, and so bringing them into the tax system leads to a larger shift than in the previous case. On the other hand, the third row keeps the initial share of income going to the fixed source-location factor the same as in the base case, but reduces the share of income going to managerial skill and raises the share going to capital. This reduces the distortion of source-based taxation, which increases the initial source-based tax rates and reduces the extent to which the tax system shifts toward destination-based taxation under the two-tax regime.

The last two rows of the table consider changes in the responsiveness of consumption to changes in prices, and are also useful in showing the potential range for the destination-based tax rate. In the fourth row, the Cobb-Douglas preference parameter for good 1 utility is lower than in the base case but the Cobb-Douglas production parameter in the second-stage production function is higher, representing a higher return to scale. In the last row, we consider the opposite of both these two changes. In each case, these changes induce offsetting effects on the equilibrium level of the consumption of good 1, which rises with stronger demand and also with more productive second stage production. This makes the net impact on private consumption, and hence the desired revenue for public spending, ambiguous in each of the last two rows of the table. For the chosen parameter values, tax revenue and public spending fall in the fourth row and rise in the fifth.

The responsiveness of consumption to source-based cash-flow taxes is higher where second-stage returns to scale are higher (i.e., in the fourth row) because the supply curve for second-stage production is flatter. For this simulation, the option to reduce source- 
based taxes in favor of destination-based taxes results in a corner solution in which each country sets its destination-based tax to 1 . This outcome is possible because the destination-based tax is non-distortionary, so there is no concern about the nonlinear increase in deadweight loss for so high a tax. In the last simulation, however, where consumption of good 1 changes less with source-based taxes (because the second-stage returns to scale are low), the source-based tax has less impact on the scale of production of good 1 and is hence less distortionary. This also leads to a corner solution for the destination-based tax, but in this case one where the destination-based tax is not used even when it is available. In this simulation, the ability to shift taxes to foreign shareholders is not worth giving up even at the high initial source-based tax rate.

\section{Results for Other Tax Systems}

\subsection{Source-based capital income taxation}

To capture an income tax in our one-period model, we use the fact that the allowances for depreciation consistent with income taxation are equivalent to immediate expensing of a fraction of investment costs (rather than full expensing under the cash-flow tax). We let $\mu\left(\mu^{*}\right)$ be the fraction of investment that is non-deductible in the home (foreign) country. This affects two of the firm's first-order conditions, as follows:

$$
\begin{array}{ll}
k: & p_{1}^{*} h^{* \prime}\left(f_{1}-f_{1}^{*}\right)\left(1-t^{*}\right)+\left(1-q f_{1}\right)\left(t-t^{*}\right)-\left(t \mu-t^{*} \mu^{*}\right)=0 \\
K: & p_{1}^{*} h^{* \prime}=\frac{1}{f_{1}^{*}}\left(1+\frac{t^{*}}{1-t^{*}} \mu^{*}\right)
\end{array}
$$

As is well known, an income tax distorts investment decisions by raising the cost of capital, as implied by (3.11"). Because this effect depends on the tax rate, then as implied 
by (3.9"), the marginal product of capital may differ between the two countries even when the tax base is the same $\left(\mu=\mu^{*}\right)$ and there is no transfer price manipulation. These effects are in addition to those described above in the context of the cash-flow tax.

Since most countries operate a source-based capital income tax instead of a sourcebased cash-flow tax, it is useful to determine how the results in the previous section are affected by starting with an income tax. We address two questions. First, would a country wish to have an income tax at all, assuming the use of a source basis? We model this by asking whether a marginal increase in $\mu$ (starting at $\mu=0$ ) matched by a reduction in the tax rate, $s$, to maintain revenue neutrality, would improve welfare. Second, beginning with a source-based capital income tax, is it optimal for a country to unilaterally move towards a destination-based cash-flow tax? We model this by fixing $\mu$, and following same approach as above by reducing the source-based income tax rate, $s$, and increasing the destinationbased cash-flow tax rate, $z$, while maintaining revenue neutrality.

In the first case, as above, a switch towards an income tax would be optimal if:

$$
\frac{d Y / d s}{d T / d s}<\frac{d Y / d \mu}{d T / d \mu}
$$

The general condition for optimality in this case, set out in Appendix A, does not provide a definitive answer to the question. This remains true even under a simplified set of conditions, in which the two countries are initially in a symmetric equilibrium, with $s=$ $s^{*}$ and $\beta=\beta^{*}$, in which case there is no transfer price manipulation, no net exports $\left(e=e^{*}\right)$, and the effects on prices are the same in both countries.

This indicates that in our setting, the well-known results of Gordon (1986) in a small open economy do not necessarily hold. As in the Gordon model, the capital income tax 
introduces additional distortions to the level and location of investment, which reduces welfare. On the other hand, unlike in the Gordon model (because here neither economy is assumed to be "small"), for a given level of activity and a given tax rate, a broadening of the tax base towards an income tax tends to increase the level of tax exporting, which increases domestic welfare. Only in the special case as $s \rightarrow 0$, does the condition (5.1) yield a definitive result against taxing capital income. That is, starting at a symmetric equilibrium with $s=0$, condition (5.1) does not hold. In this case, the cost of additional distortions arising from using a capital income tax exceed any advantages from tax exporting.

For the second case, a switch from a source-based capital income tax to a destination-based cash-flow tax is again optimal if $\frac{d Y}{d s}+\frac{d T}{d s}<0$, where $s$ is the rate of capital income tax. Relative to the condition above which started with the source-based cash-flow tax, starting with a capital income tax, there are now additional terms depending on $\mu$. The trade-off has the same elements as when comparing only cash-flow taxes. Appendix A shows that in the case of symmetric countries, (4.11) becomes

$$
-s\left(\frac{f_{2}}{f_{1}} \frac{d m}{d s}\right)-s \mu \frac{d k}{d s}>\beta^{*}\left(p_{1} c_{1}-(1-\mu) k\right)
$$

The second term on the LHS reflects the fact that the income tax increases the costs of distortions by raising the cost of capital. The impact of the income tax on the second term on the RHS implies that with a broader tax base a marginal reduction in the sourcebased tax rate has a larger negative impact on tax exporting. In general, then, the nature of the trade-off is similar, though more complex, than in the comparison of cash-flow taxes. 


\subsection{Cash-flow tax with apportionment by sales}

Formula apportionment has often been considered as a solution to the difficulty of determining the location of the tax base, and has been proposed by the European Commission (2016) as a replacement for existing corporation taxes in Europe. Its properties have been analyzed by Gordon and Wilson (1986), who demonstrated that for a standard corporate income tax, a three-factor formula based on the location of property, payroll and sales could be examined as, in effect, three forms of distortionary taxation. It is clear that a formula based on property or payroll would affect location incentives, so we focus on the case where apportionment of the cash-flow tax relies solely on the destination of sales - that is, where the consumer resides, as is increasingly used among US states and has been proposed for the international level by Avi-Yonah and Clausing (2008).

We assume here that the apportionment factor is based on the location of the consumption of good 1 only, which follows naturally if the multinational does not also produce good $2 .{ }^{19}$ Consequently, the equilibrium competitive price for good 2 will still be 1 , and the utility maximization conditions in expression (3.1) still holds. Post-tax profits are:

$$
\pi=\left(p_{1} c_{1}+p_{1}^{*} c_{1}^{*}-K\right)\left[1-t a-t^{*}(1-a)\right]
$$

where

$$
a=\frac{p_{1} c_{1}}{p_{1} c_{1}+p_{1}^{*} c_{1}^{*}} .
$$

\footnotetext{
19 There is potentially wide scope for the multinational to allocate more profit to the low tax country, either by purchasing low-margin domestic businesses (in our model, selling good 2) in that jurisdiction, and hence increasing total sales there to which its good-1 profits are allocated, or by routing some of the good 1 produced and ultimately sold in the high tax country through an independent low-margin company in the low-tax country, again increasing its total sales in the low-tax country to which good-1 profits are allocated. We abstract from these avoidance opportunities but note that they present a major challenge to adopting apportionment based on sales.
} 
Using (5.3), we can derive the firm's optimal conditions with respect to $k, m, K$, and $x 1$. For the condition with respect to $k$, we have:

$$
\left[1-t a-t^{*}(1-a)+\frac{a\left(t-t^{*}\right) \pi^{G}}{p_{1} c_{1}+p_{1}^{*} c_{1}^{*}}\right] p_{1}^{*} h^{\prime}\left(x_{1}^{*}\right)\left[f_{1}(k, m)-f_{1}\left(k^{*}, m^{*}\right)\right]=0
$$

where $\pi^{G}$ equals pre-tax profits. Hence, the term $\left(f_{1}-f_{1}^{*}\right)$ must equal 0 and (3.3) still holds; likewise, from a similar first-order condition with respect to $m$, so does condition (3.4), so there is still production efficiency.

As shown in Appendix A, the condition with respect to $K$ yields:

$$
\left[1+\frac{a\left(t-t^{*}\right) \pi^{G}}{\left(1-t a-t^{*}(1-a)\right)\left(p_{1} c_{1}+p_{1}^{*} c_{1}^{*}\right)}\right] p_{1}^{*} h^{\prime}\left(x_{1}^{*}\right)=\frac{1}{f_{1}\left(\frac{K}{2}, \frac{M}{2}\right)}
$$

A similar condition for the home country follows from the first-order condition for $x_{1}$. Expression (5.5) indicates that there will be an effective tax or a subsidy on consumption according to whether the home tax rate is higher or lower than the tax rate abroad. If $t>$ $t^{*}$, for example, sales are discouraged at home and encouraged abroad by the incentive to shift the location of profits for tax purposes. Apportioning a cash-flow tax based on sales will therefore generally distort consumption in both countries, although not production.

We now consider a shift from a source-based cash-flow tax towards a salesapportioned cash-flow tax, focusing on the simple case of a symmetric initial equilibrium. From the previous logic, home-country welfare will increase with the introduction of a sales-apportioned tax at rate $t$ as an equal-yield replacement for a source-based tax at rate $s$ if and only if: 


$$
-\frac{d Y / d t}{d T / d t}<-\frac{d Y / d s}{d T / d s}
$$

that is, if the marginal cost of funds is lower for the sales-apportioned tax upon its introduction than for the existing source-based tax. Since the right-hand of (5.6) - the marginal cost of funds for the source-based tax - will be the same as before, we need only consider the left-hand side of the expression. After-tax profits are:

$$
\pi=\left(1-t a-t^{*}(1-a)\right)\left\{\begin{array}{c}
(1-s)\left(p_{1} c_{1}-k\right) \\
+\left(1-s^{*}\right)\left(p_{1}^{*} c_{1}^{*}-k^{*}\right)+q\left(e^{*}-e\right)\left(s-s^{*}\right)
\end{array}\right\} .
$$

The effect of a change in $t$ on real income, starting at $t=0$, is therefore:

$$
\frac{d Y}{d t}=\beta \frac{d \pi}{d t}-c_{1} \frac{d p_{1}}{d t}=-\beta(1-s)\left(p_{1} c_{1}-k\right)-(1-\beta(1-s)) c_{1} \frac{d p_{1}}{d t}+\beta\left(1-s^{*}\right) c_{1}^{*} \frac{d p_{1}^{*}}{d t}
$$

Now consider the changes in $T$. Using the definition of net exports, we have:

$$
T=a t\left((1-s)\left(p_{1} c_{1}-k\right)+\left(1-s^{*}\right)\left(p_{1}^{*} c_{1}^{*}-k^{*}\right)\right)+s\left(p_{1} c_{1}-k-q x_{1}+q f(k, m)\right)
$$

and

$$
\frac{d T}{d t}=(1-s)\left(p_{1} c_{1}-k\right)+s\left(c_{1} \frac{d p_{1}}{d t}+q f_{2} \frac{d m}{d t}\right)=(1-s)\left(p_{1} c_{1}-k\right)+s c_{1} \frac{d p_{1}}{d t},
$$

where the last equality comes from the fact, discussed above, that the sales-apportioned tax does not distort the location of $M$. Using the fact that $c_{1}=c_{1}^{*}, \beta=\beta^{*}$, and $s=s^{*}$ in the initial symmetric equilibrium, we therefore may express the left-hand side of (5.6) as:

$$
\frac{-\left(\frac{1}{2}(1-s)\left(p_{1} c_{1}-k\right)+\left(1-\frac{1}{2}(1-s)\right) c_{1} \frac{d p_{1}}{d t}-\frac{1}{2}(1-s) c_{1} \frac{d p_{1}^{*}}{d t}\right)}{(1-s)\left(p_{1} c_{1}-k\right)+s c_{1} \frac{d p_{1}}{d t}}
$$


To evaluate this expression, we use (5.5) for the home and foreign country, from which we obtain, at $t=0$,

$$
-\frac{\left(p_{1} c_{1}-k\right) p_{1} h^{\prime}}{p_{1} c_{1}}+\frac{d\left(p_{1} h^{\prime}\right)}{d t}=\frac{d\left(p_{1}^{*} h^{*^{\prime}}\right)}{d t}
$$

Consider first the special case with no consumption rents, i.e., $h^{\prime}$ is constant and equal across the two countries. Then (5.12) reduces to $-\frac{\left(p_{1} c_{1}-k\right)}{c_{1}}+\frac{d p_{1}}{d t}=\frac{d p_{1}^{*}}{d t}$ and the marginal cost of funds in (5.11) equals 1 ; that is, $d Y / d t=-d T / d t$ in this case, because there is no tax exporting (and no first-order distortion). This is precisely the condition that holds for the destination-based tax, and therefore the condition from that analysis, (4.11), holds in this case as well; when there is no tax exporting under the sales-apportioned tax, the decision is the same as under the destination-based tax.

However, if there are consumption rents, then $-\frac{\left(p_{1} c_{1}-k\right) p_{1}}{p_{1} c_{1}}+\frac{d p_{1}}{d t}<\frac{d p_{1}^{*}}{d t}$, since some of the tax wedge will show up in a reduced final-goods producer price as the demand for good 1 falls in the home country. This reduces the numerator (5.11) because of tax exporting: with consumption rents, some of the burden of the sales-apportioned tax falls on producers, and some of this burden on producers is borne by foreign owners.

Note that this differs from the case of the destination-based tax because there is no substitution away from consumption of good 1 in that case. While the substitution results in a distortion here, the introduction of a small tax has only second-order deadweight loss (which does not show up in (5.11)) but first-order incidence effects. Thus, for a small shift from source-based taxation, sales apportionment may be preferable to a destination-based approach, the more favorable incidence possibly outweighing the small domestic 
consumption distortions. But the trade-off would presumably be less favorable for a larger tax shift due to the nonlinearity of deadweight loss, and also ignores the additional problems of sales-apportioned taxes (see footnote 19), which are not in the model.

\section{Conclusions}

Given the relatively technical nature of this discussion, a brief summary of the key results may be helpful. In the base model as set out above, the choice between the various forms of taxation amounts to a trade-off between two factors. First there may a reduction in aggregate welfare due to the deadweight costs generated by distortions to behavior. Second, one country may be able to export at least part of the effective incidence of a tax to residents of the other country.

The source-based cash-flow tax distorts the pattern of production and consumption, and these distortions tend to be exacerbated by the possibility of profit shifting through transfer price manipulation. However the tax falls to some extent on firm owners, so that with cross-border ownership of firms, part of the incidence of the may be exported. Including the normal return in the tax base, as in a capital income tax, changes the nature and size of the deadweight cost and also the benefits of tax exporting, but it does not change the fact of the tax having these two offsetting effects. By contrast, the destinationbased cash-flow tax does not create a deadweight cost. On the other hand, because of price effects, it falls on consumption out of profit income by domestic residents, and it is therefore not exported. The optimal choice of the mix of tax instruments therefore depends only on the trade-offs within the source-based taxes. As to sales apportionment, it shares

some of the characteristics of source-based and destination-based taxation, with elements 
of both tax exporting and economic distortion, but with some of the benefit of taxing based on the location of consumers.

Clearly, if the countries instead cooperated with each other, then the tax exporting effect would be irrelevant, since the possibility of side payments between the countries would mean that minimizing the aggregate deadweight costs should be optimal. In this case it is clear that the destination-based cash-flow tax would be optimal. Generally, though, the choice is more complex. And, of course, a full evaluation of alternative systems would also need to take into account factors that we have not included in our model, such as partial mobility of consumers through cross-border shopping, and more general issues of implementation and enforcement. ${ }^{20}$

${ }^{20}$ Devereux and de la Feria (2014) and Auerbach et al. (2017) discuss destination-based tax implementation issues. 


\section{REFERENCES}

Arulampalam, W., M.P. Devereux and G. Maffini (2012) "The Direct Incidence of Corporation Tax on Wages", European Economic Review 56, 1038-1054.

Auerbach, A.J. (1997) "The Future of Fundamental Tax Reform", American Economic Review 87, 143-146.

Auerbach, A.J., M.P. Devereux, M. Keen and J. Vella (2017) "Destination-Based Cash-flow taxation," Oxford University Centre for Business Taxation Working Paper 17/01, January.

Avi-Yonah, R. (2000) "Globalization, Tax Competition, and the Fiscal Crisis of the Welfare State", Harvard Law Review, 113, 1573-1676.

Avi-Yonah, R. and K. Clausing (2008) "Reforming Corporate Taxation in a Global Economy: A Proposal to Adopt Formulary Apportionment" in Jason Furman and Jason E. Bordoff, eds. Path to Prosperity: Hamilton Project Ideas on Income Security, Education, and Taxes, 319344.

Becker, J. and R. Davies (2014) “A negotiation-based model of tax-induced transfer pricing”, CESifo Working Paper Series 4892, CESifo Group Munich.

Becker, J. and C. Fuest (2010) "Taxing Foreign Profits with International Mergers and Acquisitions", International Economic Review 51, 171-186.

Bond, S.R. and M.P. Devereux (2002) "Cash-flow taxes in an Open Economy", CEPR Discussion Paper 3401.

Bradford, D. (2003) "The X Tax in the World Economy", CEPS Working Paper 93, Princeton.

De Mooij, R.A. and S. Ederveen (2008) "Corporate tax elasticities: a reader's guide to empirical findings", Oxford Review of Economic Policy 24.4, 680-697.

Devereux, M.P. and R. de la Feria (2014) "Defining and implementing a destination-based corporate tax", Oxford University Centre for Business Taxation working paper 14/07.

Devereux, M.P., C. Fuest and B. Lockwood (2015) "The Taxation of Foreign Profits: a Unified View", Journal of Public Economics 125, 83-97.

Devereux, M.P. and R. Griffith (1998) "Taxes and the location of production: evidence from a panel of US multinationals", Journal of Public Economics 68.3, 335-367.

European Commission (2016) "Proposal for a Council Directive on a Common Consolidated Corporate Tax Base (CCCTB)", COM(2016) 683 final.

Gordon, R.H. (1986) "Taxation of Investment and Savings in a World Economy", American Economic Review 76, 1086-1102. 
Gordon, R.H. and J.D. Wilson (1986) "An Examination of Multijurisdictional Corporate Income Taxation under Formula Apportionment", Econometrica 54, 1357-1373.

Grubert, H. and T. S. Newlon (1997) "Taxing Consumption in a Global Economy", Washington D.C.: American Enterprise Institute.

Habu, K. (2017) "How much tax do companies pay in the UK", Oxford University Centre for Business Taxation Working Paper 17/14.

Hirshleifer, J. (1956) "On the economics of transfer pricing", The Journal of Business 29.3, 172184.

Hong, Q. and M. Smart (2010) "In praise of tax havens: International tax planning and foreign direct investment", European Economic Review 54, 82-95.

Huizinga, H. and S. Bo Neilsen (1997) "Capital income and profit taxation with foreign ownership of firms", Journal of International Economics 42, 149-165.

Keen, M. and S Lahiri (1998) "The Comparison between Destination and Origin Principles under Imperfect Competition," Journal of International Economics 45, 323-350.

Lockwood, B. (1993) "Commodity Tax Competition under Destination and Origin Principles" Journal of Public Economics 53, 141-162.

Lockwood, B. (2001) "Tax Competition and Tax Co-ordination under Destination and Origin Principles: a Synthesis", Journal of Public Economics 81, 279-319.

Meade, J. et al. (1978) The Structure and Reform of Direct Taxation, London: Allen and Unwin.

OECD (2015) Explanatory Statement, OECD/G20 Base Erosion and Profit Shifting Project, OECD. www.oecd.org/tax/beps-explanatory-statement-2015.pdf

Ways and Means Committee, U.S. House of Representatives (2016) A Better Way Forward. http://abetterway.speaker.gov/_assets/pdf/ABetterWay-Tax-PolicyPaper.pdf 


\section{APPENDIX A: Derivations of various results in the main text}

1. Derivation of results around (4.11) that (1) $\frac{d\left(e-e^{*}\right)}{d s}<0$; and (2) consumer prices are the same for an initial symmetric equilibrium with marginal cost pricing:

Combining expressions (3.9') and (3.11') and then taking the derivative with respect to $s$,

$$
\frac{1}{f_{1}^{*}}\left(f_{1}-f_{1}^{*}\right)\left(1-s^{*}\right)+\left(1-q f_{1}\right)\left(s-s^{*}\right)=0
$$

$$
\frac{1}{f_{1}^{*}}\left(1-s^{*}\right) \frac{d f_{1}}{d s}-\frac{f_{1}}{f_{1}^{* 2}}\left(1-s^{*}\right) \frac{d f_{1}^{*}}{d s}+\left(1-q f_{1}\right)-q\left(s-s^{*}\right) \frac{d f_{1}}{d s}=0
$$

With initial marginal cost pricing, $q=1 / f_{1}^{*}=1 / f_{1}$, so (A.2) reduces to

$$
(1-s) \frac{d f_{1}}{d s}=\left(1-s^{*}\right) \frac{d f_{1}^{*}}{d s}
$$

Combining expressions (3.10') and (3.11') and then differentiating with respect to $s$ yields,

$$
\begin{aligned}
& \frac{1}{f_{1}^{*}}\left(f_{2}-f_{2}^{*}\right)\left(1-s^{*}\right)-q f_{2}\left(s-s^{*}\right)=0 \\
& \frac{1}{f_{1}^{*}}\left(1-s^{*}\right) \frac{d f_{2}}{d s}-\frac{1}{f_{1}^{*}}\left(1-s^{*}\right) \frac{d f_{2}^{*}}{d s}-\frac{\left(f_{2}-f_{2}^{*}\right)}{f_{1}^{* 2}}\left(1-s^{*}\right) \frac{d f_{1}^{*}}{d s}+-q f_{2}-q\left(s-s^{*}\right) \frac{d f_{2}}{d s}=0
\end{aligned}
$$

Using initial marginal cost pricing, $q=\frac{1}{f_{1}^{*}}$, and using (A.4) to substitute for $\left(f_{2}-f_{2}^{*}\right)$ yields:

$$
\left(1-s^{*}\right) \frac{d f_{2}}{d s}-\left(1-s^{*}\right) \frac{d f_{2}^{*}}{d s}-\frac{f_{2}}{f_{1}^{*}}\left(s-s^{*}\right) \frac{d f_{1}^{*}}{d s}+-f_{2}-\left(s-s^{*}\right) \frac{d f_{2}}{d s}=0
$$

Starting from an equilibrium in which $s=s^{*}$, expressions (A.3) and (A.6) reduce to:

$$
\frac{d f_{1}}{d s}=\frac{d f_{1}^{*}}{d s}
$$

and 


$$
\frac{d f_{2}}{d s}-\frac{d f_{2}^{*}}{d s}=\frac{f_{2}}{1-s}
$$

Combining (A.7) and (A.8) and noting that starting from a symmetric equilibrium the second derivatives of the production functions are the same across countries, we obtain:

$$
\begin{aligned}
& \frac{d m^{*}}{d s}-\frac{d m}{d s}=-\frac{f_{11}}{D} \frac{f_{2}}{(1-s)}>0 \\
& \frac{d k^{*}}{d s}-\frac{d k}{d s}=\frac{f_{12}}{D} \frac{f_{2}}{(1-s)}>0
\end{aligned}
$$

where $D=f_{11} f_{22}-f_{12} f_{21}>0$ is the determinant of the Hessian of the production function. Since both $m$ and $k$ shift abroad with an increase in $s$, so must the first stage of production.

Note that (3.9)-(3.12) imply that $p_{1} h^{\prime}=p_{1}^{*} h^{*^{\prime}}$. Since marginal utility equals the price in each country, this implies that $u^{\prime}\left(h\left(x_{1}\right)\right) h^{\prime}\left(x_{1}\right)=u^{*^{\prime}}\left(h\left(x_{1}^{*}\right)\right) h^{\prime}\left(x_{1}^{*}\right)$, where we have used the fact that the functions $h($.$) and h^{\prime}($.$) are the same in the two countries. Thus, if$ preferences are the same in the two countries, we have $u^{\prime}\left(h\left(x_{1}\right)\right) h^{\prime}\left(x_{1}\right)=u^{\prime}\left(h\left(x_{1}^{*}\right)\right) h^{\prime}\left(x_{1}^{*}\right)$. This expression is satisfied if $x_{1}=x_{1}^{*}$, and the solution is unique: since both $h^{\prime \prime}$ and $u$ " are negative, the derivative of either side with respect to its argument is negative, so the equality cannot hold for $x_{1} \neq x_{1}^{*}$. Hence the increase in $s$ decreases domestic production but does not change relative consumption. Therefore, domestic exports fall with $s$.

Note also that, because consumption of good 1 remains the same in the two countries, so must the price of good 1, again under the assumption of common preferences, equal initial tax rates, and marginal cost pricing. 


\section{Source-based capital income taxation}

As explained in Section 5.1, we model an income tax by permitting a partial deduction for the cost of capital expenditure. Specifically, instead of permitting a deduction of $K$, the capital income tax permits only a deduction of $(1-\mu) K$, where $\mu K$ accounts for the normal return to capital. The impact of this change on the first order conditions in the source-based case are set out in Section 5.1, which discusses the incentive to marginally increase $\mu$, offset by a fall in the tax rate, $s$, to maintain revenue neutrality. The condition for this to improve welfare is (5.2). In the general case, this condition can be shown to be:

$$
\begin{aligned}
& \frac{-\beta\left[p_{1} c_{1}+q\left(e-e^{*}\right)-(1-\mu) k\right]-[1-\beta(1-s)] c_{1} \frac{d p_{1}}{d s}+\beta\left(1-s^{*}\right) c_{1}^{*} \frac{d p_{1}^{*}}{d s}}{\left[p_{1} c_{1}+q\left(e-e^{*}\right)-(1-\mu) k\right]+s\left(q-\frac{1}{f_{1}}\right)\left(\frac{d\left(e-e^{*}\right)}{d s}\right)+s\left(\frac{f_{2} d m}{f_{1} d s}\right)+s \delta \frac{d k}{d s}+s c_{1} \frac{d p_{1}}{d s}}< \\
& \frac{-\beta s k-[1-\beta(1-s)] c_{1} \frac{d p_{1}}{d \mu}+\beta\left(1-s^{*}\right) c_{1}^{*} \frac{d p_{1}^{*}}{d \mu}}{s k+s\left(q-\frac{1}{f_{1}}\right)\left(\frac{d\left(e-e^{*}\right)}{d \mu}\right)+s\left(\frac{f_{2} d m}{f_{1} d \mu}\right)+s \delta \frac{d k}{d \mu}+s c_{1} \frac{d p_{1}}{d \mu}}
\end{aligned}
$$

Where the two countries are initially in a symmetric equilibrium, with $s=s^{*}$ and $\beta$ $=\beta^{*}=1 / 2$, then there is no transfer pricing manipulation $\left(q=1 / f_{1}\right)$, no exports $\left(e=e^{*}\right)$, and the terms $c_{1}$ and $d p_{1} / d s$ and $d p_{1} / d \delta$ are the same in both countries. In this case, the expression simplifies to:

$$
\frac{-\beta\left[p_{1} c_{1}-(1-\mu) k\right]-s c_{1} \frac{d p_{1}}{d s}}{\left[p_{1} c_{1}-(1-\mu) k\right]+s\left(\frac{f f_{2} d m}{f_{1} d s}\right)+s \delta \frac{d k}{d s}+s c_{1} \frac{d p_{1}}{d s}}<\frac{-\beta k-c_{1} \frac{d p_{1}}{d \mu}}{k+\left(\frac{f_{2} 2 m}{f_{1} d \mu}\right)+\mu \frac{d k}{d \mu}+c_{1} \frac{d p_{1}}{d \mu}}
$$

As $s \rightarrow 0$, the expression simplifies to

$$
-\left(\frac{f_{2}}{f_{1}} \frac{d m}{d \mu}\right)-\mu \frac{d k}{d \mu}<-c_{1} \frac{d p_{1}}{d \mu}
$$


which is never satisfied because an increase in the capital income tax shifts production factors away from the home country (and hence the left-hand side is positive) and raises the production cost and hence the price of good 1 (so that the right-hand side is negative).

In analyzing a marginal switch from a source-based capital income tax to a destination-based cash-flow tax, (4.10) has some additional terms to reflect the partial deduction of capital expenditure, and becomes

$$
\begin{aligned}
-s\left(\frac{f_{2}}{f_{1}} \frac{d m}{d s}\right)- & s\left(q-\frac{1}{f_{1}}\right)\left(\frac{d\left(e-e^{*}\right)}{d s}\right)-s \mu \frac{d k}{d s} \\
& >\beta^{*}\left[p_{1} c_{1}+q\left(e-e^{*}\right)-(1-\mu) k\right]+\beta\left(1-s^{*}\right) c_{1}^{*} \frac{d p_{1}^{*}}{d s}-\beta^{*}(1-s) c_{1} \frac{d p_{1}}{d s}
\end{aligned}
$$

In the symmetric case, this becomes (5.2).

\section{Sales apportionment}

From (5.3), profits are:

(A.14) $\pi=\left(p_{1} h\left(x_{1}\right)+p_{1}^{*} h\left(f(k, m)+f(K-k, M-m)-x_{1}\right)-K\right)\left[1-t a-t^{*}(1-a)\right]$,

where $\quad a=\frac{p_{1} h\left(x_{1}\right)}{p_{1} h\left(x_{1}\right)+p_{1}^{*} h\left(f(k, m)+f(K-k, M-m)-x_{1}\right)}$.

Differentiating with respect to $K$ yields:

$$
\left(p_{1}^{*} h^{\prime}\left(x_{1}^{*}\right) f_{1}\left(k^{*}, m^{*}\right)-1\right)\left[1-t a-t^{*}(1-a)\right]-\pi\left(t-t^{*}\right) \frac{d a}{d K}=0 .
$$

But $\frac{d a}{d K}=-\frac{a}{p_{1} c_{1}+p_{1}^{*} c_{1}^{*}} p_{1}^{*} h^{\prime}\left(x_{1}^{*}\right) f_{1}\left(k^{*}, m^{*}\right)$, so (A.15) simplifies to:

$$
\left[1+\frac{a \pi^{G}\left(t-t^{*}\right)}{\left[1-t a-t^{*}(1-a)\right]\left(p_{1} c_{1}+p_{1}^{*} c_{1}^{*}\right)}\right] p_{1}^{*} h^{\prime}\left(x_{1}^{*}\right)=\frac{1}{f_{1}\left(k^{*}, m^{*}\right)}
$$


Expression (5.5) follows from the fact that there is production efficiency. A similar expression for the home country follows from the first-order condition with respect to $x_{1}$.

\section{APPENDIX B: The impact of variations in relative country size}

In the tax competition literature, a standard finding is that the optimal behavior of small and large countries differs. How would differences in country size affect our results? Intuitively, the smaller the country's relative size, the greater the responsiveness of the multinational to changes in its tax policy. But a smaller country may also own a smaller share of the multinational's shares, and so may see a greater opportunity to export taxes to foreign shareholders.

Both of these effects, which work in opposite directions, are present as a country's size falls. However, at least where the country's ownership share is proportional to its size, the effects exactly cancel and changes in relative size have no effect on the choice between source-based and destination-based taxes. This somewhat surprising result may be specific to our model, but it does illustrate that the direction of the net impact of a change in relative size is not clear.

We suppose that, rather than there being one individual with unit endowment in each country, there are $\alpha$ and $\alpha^{*}$, with $\alpha+\alpha^{*}=1$. Also assume that the shares of ownership in the multinational are the same, i.e., that $\beta=\alpha$ and $\beta^{*}=\alpha^{*}$. In order to scale the location-specific fixed factors to country size, let the production functions $f(\cdot)$ and $h(\cdot)$ be expressed in per capita terms, with $f(\cdot)$ the same across countries and $h(\cdot)$ the same as well when preferences are

identical. For this case, it may be shown that expression (4.11) still holds, with $c_{1}, k$, and $m$ all now interpreted in per capita rather than absolute terms. Thus, as the country's size falls, tax 
exporting increases and this makes keeping the source-based tax more attractive. As to the lefthand side of (4.11), note that the expression accounting for the use of $M$ is now

$$
M=\beta m+\beta^{*} m^{*}
$$

Thus, $\beta^{*} \frac{d m^{*}}{d s}+\beta \frac{d m}{d s}=0$, so (A.9) implies that $\frac{d m}{d s}=\beta^{*} \frac{f_{11}}{D} \frac{f_{2}}{(1-s)}$, which increases in size as the home country's relative size decreases, i.e., as $\beta^{*}$ increases. Thus, the left- and righthand sides of (4.11) are both scaled by $\beta^{*}$ and the effects of country size on the taxexporting and distortion effects cancel.

\section{APPENDIX C: The impact of local ownership of fixed factors}

We have assumed that all three sources of rents accrue to multinationals. How would our results change if a greater share of these rents accrued exclusively to domestic factors, rather than to shareholders (some foreign) of the multinational? Intuition suggests that this would reduce the scope for tax exporting and make adoption of destination-based taxation more attractive, but is this actually the case?

We modify the model, assuming that rents to fixed factors accrue to domestic residents instead of to the multinational. There are two fixed factors implicit in the production functions $f(k, m)$ and $h\left(x_{1}\right)$. To make these explicit, we can rewrite the intermediate production function $f(\cdot)$ and the final production function $h(\cdot)$ each as having an additional argument, e.g., $f(k, m, r)$ and $h\left(x_{1}, \rho\right)$, with constant returns to scale and (assuming the multinational is a price-taker with respect to these fixed factors) with the corresponding competitive returns to these arguments denoted by $q_{r}$ and $q_{\rho}$ in the home country and likewise with an asterisk in the foreign country. 
With these additional factors taken into account, the firm's objective is to maximize profits as given in expression (3.8) minus $\left(q_{r} r+q_{\rho} \rho\right)(1-s)+\left(q_{r}^{*} r^{*}+q_{\rho}^{*} \rho^{*}\right)\left(1-s^{*}\right)$, assuming that the fixed-factor rents are taxed at the same tax rate in each country as the multinational is. With this modification of its objective, the firm's first-order conditions given in $\left(3.9^{\prime}\right)-\left(3.12^{\prime}\right)$ are unchanged, and there are four new first-order conditions for the use of each of the fixed factors:

(C.1) $\rho: \quad p_{1} h_{2}=q_{\rho}$

(C.2) $\rho^{*}: \quad p_{1}^{*} h_{2}^{*}=q_{\rho}^{*}$

(C.3) $r: \quad p_{1}^{*} h^{*^{\prime}} f_{3}\left(1-s^{*}\right)-q f_{3}\left(s-s^{*}\right)=q_{r}(1-s)$

(C.4) $r^{*}: \quad p_{1}^{*} h^{*^{\prime}} f_{3}^{*}=q_{r}^{*}$

where $h_{2}=c_{1}-h^{\prime} x_{1}$ and $f_{3}=f-f_{1} k-f_{2} m$ (and similarly for the foreign country). Note that by the symmetry of the set-up, it also follows that $p_{1} h^{\prime} f_{3}=q_{r}$. In equilibrium, of course, the four fixed factor prices will be determined by the market clearing conditions that demand for each of the fixed factors equals its unit supply.

With this modification, consider again the issue of whether the home country will wish to shift from a source-based tax to a destination-based tax. In place of equation (4.6), the income of domestic residents is

$$
y=(1-z)\left[\beta \pi+\beta^{*} D(1-s)-\beta F\left(1-s^{*}\right)\right]
$$

where $\pi$ is as defined in expression (3.8), $D=q_{r} r+q_{\rho} \rho$ and $F=q_{r}^{*} r^{*}+q_{\rho}^{*} \rho^{*}$ (and each rent quantity equals 1 in equilibrium).

Based on (C.5), the change in domestic income with respect to $s$ is now: 
(C.6) $\frac{d Y}{d s}=\frac{d y}{d s}-c_{1} \frac{d p_{1}}{d s}=\left\{\begin{array}{c}-\beta\left(p_{1} c_{1}+k-q\left(e-e^{*}\right)\right)-\beta^{*} D+ \\ (1-s)\left(\beta c_{1} \frac{d p_{1}}{d s}+\beta^{*} \frac{d D}{d s}\right)+\left(1-s^{*}\right)\left(\beta c_{1}^{*} \frac{d p_{1}^{*}}{d s}-\beta \frac{d F}{d s}\right)\end{array}\right\}-c_{1} \frac{d p_{1}}{d s}$

where the remaining terms vanish due to the envelope theorem, from the firm's maximization of $\pi-D(1-s)-F\left(1-s^{*}\right)$. Adding this expression to $d T / d s$ as defined in (4.9) yields, after some algebra:

$$
\begin{aligned}
-s\left(\frac{f_{2}}{f_{1}} \frac{d m}{d s}\right)-s(q-\bar{q}) & \left(\frac{d\left(e-e^{*}\right)}{d s}\right)>\beta^{*}\left(p_{1} c_{1}+q\left(e-e^{*}\right)-k-D\right) \\
& +\left(1-s^{*}\right) \beta\left(\mathrm{c}_{1}^{*} \frac{\mathrm{dp}}{\mathrm{ds}}-\frac{\mathrm{dF}}{\mathrm{ds}}\right)-(1-s) \beta^{*}\left(c_{1} \frac{d p_{1}}{d s}-\frac{d D}{d s}\right)
\end{aligned}
$$

where $\bar{q}=1 / f_{1}$ is the marginal cost of the intermediate good produced at home (likewise for $\bar{q}^{*}$ abroad).

Once again assuming a symmetric initial equilibrium, this expression reduces to:

$$
-s\left(\frac{f_{2}}{f_{1}} \frac{d m}{d s}\right)>\frac{1}{2}\left(p_{1} c_{1}-k-D\right)+\frac{(1-s)}{2}\left(\frac{d D}{d s}-\frac{\mathrm{dF}}{\mathrm{d} s}\right) .
$$

Since, in the symmetric equilibrium, domestic and foreign fixed factor returns are profits in each country excluding returns to managerial capital (by assumption measured at true marginal cost),

$$
D=p_{1} c_{1}-k-\bar{q} f_{2} m ; \quad F=p_{1} c_{1}-k^{*}-\bar{q} f_{2}^{*} m^{*},
$$

it may be also be shown (again using the envelope theorem) that

(C.10) $\frac{d D}{d s}=c_{1} \frac{d p_{1}}{d s}-m \frac{d\left(\bar{q} f_{2}\right)}{d s} ; \quad \frac{d F}{d s}=c_{1} \frac{d p_{1}}{d s}-m^{*} \frac{d\left(\bar{q}^{*} f_{2}^{*}\right)}{d s}$

But, using (A.7) - which implies that $\frac{d \bar{q}}{d s}=\frac{d \bar{q}^{*}}{d s}-$ and (A.8), 


$$
\begin{aligned}
& (1-s)\left(\frac{d D}{d s}-\frac{d F}{d s}\right)=(1-s)\left(m^{*} \frac{d\left(\bar{q}^{*} f_{2}^{*}\right)}{d s}-m \frac{d\left(\bar{q} f_{2}\right)}{d s}\right) \\
& =(1-s) f_{2}\left(m^{*}-m\right) \frac{d \bar{q}}{d s}+\bar{q}\left[m^{*}\left(-f_{2}+(1-s) \frac{d f_{2}}{d s}\right)-m(1-s) \frac{d f_{2}}{d s}\right]=-\bar{q} f_{2} m^{*},
\end{aligned}
$$

so (C.8) may be rewritten

(C.11) $-s\left(\frac{f_{2}}{f_{1}} \frac{d m}{d s}\right)>\frac{1}{2}\left(p_{1} c_{1}-k-\left(p_{1} c_{1}-k-\bar{q} f_{2} m\right)-\bar{q} f_{2} m^{*}\right)=\frac{1}{2}\left(\bar{q} f_{2}\left(m-m^{*}\right)\right)=0$.

Thus, unlike in the symmetric equilibrium in which all earnings go to the multinational, the home country will definitely wish to move away from the source-based tax. In this situation, with a smaller component of earnings going to the multinational and its shareholders worldwide, there are no opportunities for tax exporting because there are no domestic production or consumption rents accruing to foreigners.

\section{Appendix D. Multinational's advantage as a public good}

We have treated the multinational as possessing a firm-specific mobile factor, managerial capital, which is in fixed supply. But some firm-specific factors, such as patents and other intangible assets, might be better characterized as having at least some public good aspects, their use in one location not fully precluding their use in the other. How might this affect our results?

The answer depends on what assumptions we maintain about other factor inputs. To the extent that the firm still utilizes the factors of production assumed in our model, the addition of a public input would have little impact on the analysis, effectively reducing costs in both countries by increasing output given the levels of the other factors, but not altering the incentives. There would still be local decreasing returns to the use of capital and managerial capital, and still the same equilibrium conditions. On the other hand, if the firm had a public input but did not use 
managerial capital in production, the only remaining distortion would be to the internal transfer price used in the export of the firm's first-stage output from one country to the other.

\section{APPENDIX E: A Cobb-Douglas numerical simulation}

This appendix sets out a simple numerical simulation approach to illustrating the effects of transfer pricing manipulation (used in Section 3.1) and Nash equilibrium tax rates (used in Section 4.1). We assume that both countries have preferences and production characterized by Cobb-Douglas functions. The first-stage production function in each country (with “*” superscripts for the foreign country here and in the remaining equations) is:

(E.1) $f(k, m)=A k^{\alpha} m^{\gamma}$

and that the second-stage production function is:

(E.2) $h\left(x_{1}\right)=D x_{1}^{\delta}$

Preferences for good-1 consumption are:

(E.3) $u\left(c_{1}\right)=\theta c_{1}^{\varphi}$

and preferences for public good consumption are:

(E.4) $v(g)=B g^{\xi}$

For the base case, we initially assume the same values of the parameters for each country, with

$$
(A, \alpha, \gamma, D, \delta, \theta, \varphi, B, \xi)=(4,0.4,0.4,1,0.5,3,0.5,4,0.25)
$$


In Section 3.1, we consider the impact of transfer pricing manipulation on the size and allocation of production, and the size and direction of exports. We start with the benchmark case in which the transfer price is equal to the inverse marginal product of capital, so that $q=\frac{1}{f_{1}}=\frac{1}{f_{1}^{*}}$. We then allow for transfer pricing manipulation of $10 \%$ of the resulting marginal product, so that $q=0.9 / f_{1}$ in the case of underpricing and $q=1.1 / f_{1}$ in the case of overpricing, if the home country exports, with the foreign country's marginal product of capital applying if the foreign country exports. We use the initial parameter values above in evaluating production and consumption based on the first order conditions $\left(3.9^{\prime}\right)-\left(3.12^{\prime}\right)$. To allow for a lower preference for good 1 , we set either $\theta$ or $\theta^{*}=1$.

In Section 4.1, we solve for two Nash equilibria, one in which the two countries are constrained to use only source-based cash-flow taxes, and the other in which countries choose source- and destination-based cash-flow taxes simultaneously. We note in the text where we vary the assumptions about the values of the parameters.

\begin{tabular}{|l|c|c|c|c|}
\hline \multicolumn{5}{|c|}{ Parameters for Table 2 } \\
\hline & $\alpha$ & $\gamma$ & $\theta$ & $\delta$ \\
\hline Base case & 0.4 & 0.4 & 3 & 0.5 \\
\hline$k$ and $m$ less productive & 0.425 & 0.425 & 3 & 0.5 \\
\hline$k$ more productive; $m$ less productive & 0.45 & 0.35 & 3 & 0.5 \\
\hline$x$ more productive; lower preference for good 1 & 0.4 & 0.4 & 1 & 0.75 \\
\hline$x$ less productive; higher preference for good 1 & 0.4 & 0.4 & 4 & 0.25 \\
\hline
\end{tabular}

